\title{
ANALISIS KANDUNGAN GLIKOGEN PADA HATI, OTOT, DAN OTAK HEWAN
}

\author{
(Analysis Of Glicogen Content On Heart, Muscle, And Animal Brain)
}

\author{
Fatmawati Mustakin $^{1 *}$ and Mulyati M Tahir ${ }^{2)}$ \\ ${ }^{1 *}$ Sekolah Menengah Atas Negeri 12 Makassar, Indonesia \\ ${ }^{2)}$ Program Studi Ilmu dan Teknologi Pangan Departemen Teknologi Pertanian Universitas Hasanuddin \\ Makassar, Indonesia \\ ${ }^{*}$ Email Penulis Korespondensi: fatmawatimustakim99@gmail.com
}

\begin{abstract}
ABSTRAK
Glikogen adalah jenis utama karbohidrat tersimpan yang ditemukan pada hewan. Glikogen terbentuk sebagai deposit glukosa berlebih di dalam tubuh yang digunakan sebagai cadangan energi. Tujuan penelitian yaitu untuk mengetahui prosedur untuk ekstraksi glikogen dan untuk menentukan kandungan glikogen dalam beberapa bahan makanan. Metode yang digunakan adalah ekstraksi dan pengujian yodium. Bahan yang digunakan adalah TCA, etanol, $\mathrm{NaCl}$, yodium, hati ayam, hati sapi, otak sapi, sapi, dan daging ayam. Hasil yang diperoleh yaitu terjadi perubahan warna dan reandemen terhadap sampel setelah pengujian yaitu hati ayam berwarna oranye kecoklatan, hati dan daging sapi berwarna coklat sedangkan otak sapi berwarna coklat jernih dan kadar rendemen tertinggi, yaitu pada hati sapi sebesar $55 \%$, hati ayam sebesar $32,64 \%$, daging ayam sebesar $9,5 \%$, daging sapi sebesar $9,5 \%$ dan terendah ditemukan pada otak sapi yaitu $0 \%$.
\end{abstract}

Kata kunci: Glikogen, rendemen, daging sapi, daging ayam, warna

\section{ABSTRACT}

Glycogen is the main type of stored carbohydrate found in animals. Glycogen is formed as excess glucose deposits in the body which are used as energy reserves. The purpose of this analysis is to find out the procedure for glycogen extraction and to determine the glycogen content in some food ingredients. The method used is iodine extraction and testing. The materials used are TCA, ethanol, $\mathrm{NaCl}$, iodine, chicken liver, beef liver, beef brain, beef, and chicken meat. The results obtained are a change in color and revision of the sample after testing, namely brownishbrown chicken liver, brown liver and beef, while the cow's brain is clear brown and the highest yield, namely in beef liver by 55\%, chicken liver by 32, 64\%, chicken meat at 9.5\%, beef at $9.5 \%$ and the lowest is found in cow brains at $0 \%$.

Keywords : Glycogen, rendemen, beef, chicken, color

\section{PENDAHULUAN}

Terdapat beberapa komponen bahan pangan yang sangat dibutuhkan oleh tubuh salah satunya adalah karbohidrat. Karbohidrat merupakan polihidroksi aldehid dan keton yang meliputi kondensat polimer-polimer yang terbentuk.
Karbohidrat tersusun atas unsur karbon (C), hidrogen $(\mathrm{H})$, dan oksigen $(\mathrm{H})$. Salah satu jenis karbohidrat yaitu glikogen

Glikogen adalah bentuk karbohidrat yang tersimpan dalam sel hewan. Kadar glukosa yang terlalu tinggi akan disimpan sebagai cadangan energi dalam bentuk glikogen. (Haryati, Nahdifa, 
Humairah, \& Abdullah, 2019; Laras, Arista Dwi, Suloi, \& Laga, 2019; Suarsana, Pontjo, Wresdiyati, \& Bintang, 2006). Glikogen dapat kembali dipecah menjadi glukosa apabila sewaktu-waktu tubuh kekurangan energi. Glikogen banyak terdapat pada hati dan otot (Genisa, Rahman, \& Tajuddin, 2019).

Salah satu metode untuk menguji adanya glikogen pada bahan pangan yaitu dengan uji iodin. Prisip dari pengujian iodin yaitu amilum atau pati yang bereaksi dengan iodin akan membentuk warna biru, dekstrin membentuk warna merah keunguan, dan glikogen akan membentuk warna merah kecoklatan. Hal inilah yang melatarbelakangi dilakukannya penelitian karbohidrat-glikogen.

\section{METODOLOGI PENELITIAN}

\subsection{Alat}

Alat yang digunakan dalam pengujian karbohidrat-glikogen, yaitu aluminium foil, bulb (Qinuo), cawan schott (Pyrex), erlenmeyer (Pyrex) gelas ukur $100 \mathrm{ml}$ (Pyrex), kertas saring, mortar (Airtack), oven (Memmert), pipet volume (Pyrex), timbangan analitik (Sartorius), sendok tanduk, dan wadah.

\subsection{Bahan}

Bahan yang digunakan dalam pengujian karbohidrat-glikogen, yaitu TCA, etanol, $\mathrm{NaCl}$, iodin, hati ayam, hati sapi, otak sapi, daging sapi, dan daging ayam.

\subsection{Prosedur Penelitian}

\subsubsection{Pengujian Glikogen}

Pengujian glikogen dilakukan dengan cara sampel ditimbang sebanyak 5 gram dan dihaluskan menggunakan mortar kemudian ditambahkan TCA sebanyak 20 $\mathrm{ml}$. Selanjutnya sampel disaring sehingga diperoleh filtrat. Filtrat yang diperoleh dipipet sebanyak $0,5 \mathrm{ml}$ dan ditambahkan iodin sebanyak satu tetes dan diamati perubahan warna yang terjadi (Suarsana et al., 2006).

\subsubsection{Ekstraksi glikogen}

Sisa filtrat yang berisi TCA dan sampel dipipet sebanyak $10 \mathrm{ml}$ lalu dihomogenkan dan disaring sehingga diperoleh filtrat. Filtrat ditambahkan etanol sebanyak $20 \mathrm{ml}$ dan dihomogenkan. Apabila belum terbentuk endapan, maka sampel ditambahkan $\mathrm{NaCl}$ lalu di sentrifuge selama 10 menit pada kecepatan 3000 rpm. Selanjutnya, endapan yang diperoleh di oven pada suhu $60^{\circ} \mathrm{C}$, hingga sampel mencapai berat konstan

\section{HASIL DAN PEMBAHASAN}

Hasil yang diperoleh dari pengujian karbohidrat-glikogen, yaitu:

Tabel 1. Hasil Pengujian Glikogen

\begin{tabular}{|c|c|c|c|}
\hline Sampel & $\begin{array}{c}\text { Warna } \\
\text { sebelum } \\
+ \text { Iodin }\end{array}$ & $\begin{array}{c}\text { Warna } \\
\text { Setelah }+ \\
\text { Iodin }\end{array}$ & Rendemen \\
\hline $\begin{array}{l}\text { Hati } \\
\text { ayam }\end{array}$ & $\begin{array}{c}\text { Kuning } \\
\text { jernih }\end{array}$ & $\begin{array}{c}\text { Orange } \\
\text { kecoklatan }\end{array}$ & $16,4 \%$ \\
\hline $\begin{array}{l}\text { Hati } \\
\text { sapi }\end{array}$ & $\begin{array}{c}\text { Kuning } \\
\text { jernih }\end{array}$ & Cokelat & $55 \%$ \\
\hline $\begin{array}{l}\text { Daging } \\
\text { ayam }\end{array}$ & Bening & Cokelat & $1,7 \%$ \\
\hline $\begin{array}{l}\text { Daging } \\
\text { sapi }\end{array}$ & Putih keruh & Cokelat & $-1 \%$ \\
\hline $\begin{array}{l}\text { Otak } \\
\text { sapi }\end{array}$ & Bening & $\begin{array}{l}\text { Cokelat } \\
\text { Bening }\end{array}$ & $0 \%$ \\
\hline
\end{tabular}

\subsection{Glikogen}

Glikogen merupakan polisakarida simpanan utama yang terdapat pada hewan. Glukosa apabila tidak segera dimetabolisasi untuk menghasilkan energi dapat disimpan di hati atau otot sebagai glikogen. Sekitar tiga-perempat glikogen tubuh total berada di otot. Biosentesis glikogen dari glukosa disebut glikogenesis. Glikogen dalam tubuh berfungsi sebagai sumber energi untuk sebagian besar fungsi sel dan jaringan. Glikogen dalam hati berfungsi untuk 
mempertahankan kadar normal glukosa dalam darah sehingga dapat digunakan oleh semua organ yang ada di dalam tubuh. Glikogen dalam otot berfungsi untuk menghasilkan glukosa yang akan digunakan oleh sel otot sendiri (Zulma, 2018), yang menyatakan bahwa glikogen pada hati berfungsi untuk mempertahankan kadar normal glukosa dalam darah yang akan dipakai oleh semua organ yang ada di dalam tubuh, sedangkan glikogen pada otot digunakan untuk menghasilkan glukosa yang akan digunakan oleh sel otot sendiri. Glukosa yang berlebih dapat disimpan sebagai cadangan energy dalam bentuk glikogen.

\subsection{Asam trikloroasetat (TCA)}

Asam trikloroasetat (TCA) adalah analog (sama) dari asam asetat, dengan ketiga atom hidrogen dari gugus metil digantikan oleh atom-atom klorin. TCA merupakan suatu bahan kaustik yang merusak dengan cara koagulasi kimiawi protein. Penambahan trikloroasetat (TCA) pada otak sapi berfungsi untuk melarutkan kandungan kandungan protein, lemak, dan asam nukleat sehingga diperoleh glikogen saja. Hal ini sesuai dengan, yang menyatakan bahwa TCA merupakan bahan yang bersifat merusak, salah satunya protein dengan cara koagulasi kimiawi protein.

\subsection{Etanol}

Etanol merupakan pelarut organik bersifat polar yang banyak digunakan dalam berbagai pengolahan pangan. Pelarut etanol memiliki titik didih $78,4{ }^{\circ} \mathrm{C}$, bersifat mudah menguap, tidak beracun, tidak berwarna, dan mudah larut dalam air. Fungsi penambahan etanol yaitu sebagai pelarut dalam ekstraksi karena etanol mempunyai kepolaran yang tinggi sehingga senyawa resin, lemak, karbohidrat, dan senyawa organik lainnya mudah untuk dilarutkan. Selain itu, etanol dalam ekstraksi glikogen berfungsi sebagai pengendap glikogen sehingga lebih mudah dipisahkan antara glikogen dan senyawa lain yang terdapat pada sampel. Hal ini sesuai dengan (Marnoto, Haryono, Gustinah, \& Putra, 2016), yang menyatakan bahwa etanol memiliki kepolaran yang tinggi karena banyak mengandung air.

\subsection{Natrium Klorida $(\mathrm{NaCl})$}

Natrium Klorida $(\mathrm{NaCl})$ merupakan senyawa kimia berbentuk padat dan berwarna putih. $\mathrm{NaCl}$ memiliki sifat yang mudah larut dalam air. $\mathrm{NaCl}$ sering digunakan sebagai bumbu sekaligus pengawet makanan. $\mathrm{NaCl}$ memiliki tingkat osmotik yang tinggi sehingga $\mathrm{NaCl}$ memiliki tingkat konsentrasi tinggi saat dilarutkan dalam air. Struktur $\mathrm{NaCl}$ meliputi anion di tengah dan kation menempati pada rongga octahedral. Larutan garam merupakan suatu elektrolit, yang mempunyai gerakan brown dipermukaan yang lebih besar dari gerakan brown pada air murni sehingga bisa menurunkan air dan larutan ini menembah gaya kohesi antar partikel sehingga ikatan partikel menjadi lebih rapat. Gerakan brown adalah gerakan terus menerus dari partikel zat cair ataupun gas. Penambahan $\mathrm{NaCl}$ berfungsi untuk menurunkan kelarutan glikogen pada air sehingga glikogen akan mengendap. Hal ini sesuai dengan (Sudjianto, 2007), yang menyatakan bahwa $\mathrm{NaCl}$ dapat menurunkan air dan larutan ini menembah gaya kohesi antar partikel sehingga ikatan partikel menjadi lebih rapat. Hal ini dijelaskan pula oleh (Ahmad, 2016), yang menyatakan bahwa $\mathrm{NaCl}$ merupakan senyawa kimia berbentuk padat dan berwarna putih yang mudah larut dalam air.

\subsection{Uji Iodin}

Uji iodin merupakan salah satu metode pengujian yang digunakan untuk membedakan polisakarida dari disakarida dan monosakarida. Perubahan warna larutan terjadi karena dalam larutan pati terdapat unit-unit glukosa yang membentuk 
rantai heliks karena adanya ikatan dengan konfigurasi pada tiap unit glukosanya. Bentuk ini yang menyebabkan pati dapat membentuk kompleks dengan molekul yodium yang dapat masuk kedalam spiralnya. Larutan iodin yang direaksikan dengan glikogen akan membentuk warna merah sampai cokelat yang disebabkan karena adanya penyerapan iodin pada struktur cincin glikogen yang saling berikatan sehingga membentuk komples berwarna merah kecoklatan. Prisip dari pengujian iodin yaitu karbohidrat golongan polisakarida akan memberikan reaksi dengan larutan iodin akan memberikan warna spesifik bergantung pada jenis karbohidratnya. Amilosa dan iodin akan berwarna biru, amilopektin dengan iodin akan berwarna merah violet, glikogen maupun dekstrin dengan iodin akan berwarna merah coklat. Kelebihan dari metode iodin yaitu proses pengujiannya mudah dan biaya yang dikeluarkan lebih sedikit dibanding metode yang lain. kelemahan dari meode iodin yaitu hasil yang diperoleh tidak akurat. Ketidak akuratan pengujian dengan metode iodin disebabkan karena pengujian bersifat subjektif. Hal ini sesuai dengan (Musta, 2018), yang menyatakan bahwa uji iodin digunakan untuk membedakan polisakarida dari disakarida dan monosakarida.

\subsection{Otak Sapi}

Otak sapi termasuk salah satu hasil ikutan ternak yang memiliki kadar lemak yang cukup tinggi. otak sapi memiliki tekstur yang sangat lembut dengan cita rasa yang khas. Otak sapi memiliki kadar lemak sebesar 9,3\%, kadar air sebesar 78,3\%, kadar protein sebesar 9,8\%, dan karbohidrat dengan jumlah yang sangat sedikit yaitu sebesar 3\%. Komponen terbesar penyusun otak adalah fosfolipida sebesar $6 \%$ yang memiliki gugus polar (fosfat) dan gugus nonpolar (lipid). Otak sapi juga mengandung glikogen dalam jumlah yang sangat kecil. Hal ini sesuai dengan Guslina (2008), yang menyatakan bahwa otak sapi mengandung kadar lemak sebesar 9,3\%, kadar air sebesar 78,3\%, kadar protein sebesar 9,8\%, dan karbohidrat hanya sebesar 3\%. Hal ini dijelaskan pula oleh (Kusnadi, Bintoro, \& Al-Baarrii, 2012), yang menyatakan bahwa otak sapi memiliki kadar lemak sebesar 9,3\%, kadar air sebesar $78,3 \%$, kadar protein sebesar 9,8\%,

\subsection{Hasil Pengujian Glikogen}

Berdasarkan hasil yang diperoleh pada pengujian karbohidrat-glikogen yaitu terjadi perubahan warna setelah penambahan iodin pada sampel. Hati ayam setelah penambahan iodin akan membentuk warna orange kecoklatan yang menandakan bahwa mengandung sedikit glikogen, hati sapi, daging ayam, dan daging sapi membentuk warna cokelat yang menandakan mengandung sedikit glikogen, dan otak sapi membentuk warna bening yang menandakan tidak terdapat glikogen. Glikogen yang terdapat di otak tidak terdeteksi disebabkan oleh kadar glikogen yang terdapat di otak sangat kecil dan sampel otak yang digunakan sangat sedikit. Larutan iodin yang direaksikan dengan glikogen akan membentuk warna merah sampai cokelat yang disebabkan karena adanya penyerapan iodin pada struktur cincin glikogen yang saling berikatan sehingga membentuk komples berwarna merah kecoklatan. Hal ini sesuai dengan (Musta, 2018), yang menyatakan bahwa glikogen yang bereaksi dengan glikogen akan membentuk warna merah kecoklatan.

\subsection{Hasil Pengujian Rendemen}

Berdasarkan hasil yang diperoleh dari pengujian karbohidrat-glikogen diperoleh nilai rendemen pada beberapa sampel. Sampel hati sapi sebesar 55\%, hati ayam menghasilkan rendemen sebesar 32,64\%, daging ayam sebesar 9,5\%, otak sapi sebesar $0 \%$, dan daging sapi sebesar $-1 \%$. Kadar rendemen tertinggi yaitu pada hati 
sapi sebesar $55 \%$ dan terendah terdapat pada daging sapi yaitu sebesar $-1 \%$. Hal ini sesuai dengan literatur yang menyatakan bahwa kandungan glikogen terbanyak terdapat di hati $(10 \%)$ daripada otot $(1 \%)$. Namun berbeda dengan daging sapi diperoleh rendemen $-1 \%$. Nilai rendemen yang diperoleh pada daging sapi tidak sesuai, hal tersebut terjadi diduga diduga karena kesalahan saat penimbangan. Saat penimbangan berat awal sampel digunakan neraca Ohauss yang tingkat ketelitiannya 0,1 gram, sedangkan pada saat menimbang berat akhir digunakan timbangan analitik dengan ketelitian 0,001 gram. Tingkat ketelitian yang berbeda berpengaruh pada nilai rendemen. Terjadi pula kesalahan pada proses pengovenan, yaitu pengovenan terlalu lama menyebabkab sampel yang di oven habis. Hal ini sesuai dengan (Antika, Julianty, Miroah, Nurul, \& Hapsari, 2012), yang menyatakan bahwa neraca ohauss memiliki ketelitian yaitu 0,1 gram, sedangkan ketelitian neraca analitik mencapai 0,001 gram.

\section{KESIMPULAN}

Kesimpulan yang diperoleh dari pengujian ini, yaitu :

1. Prosedur ekstraksi glikogen dilakukan dengan menggunakan beberapa pelarut

2. Sampel hati ayam menghasilkan rendemen sebesar 32,64\%, hati sapi sebesar 55\%, daging ayam sebesar 9,5\%, daging sapi sebesar $29,80 \%$, dan otak sapi sebesar $0 \%$.

Saran untuk penelitian selanjutnya yaitu sebaiknya digunakan pula metode lain misalnya uji benedict dan barfoed dalam menguji glikogen sehingga hasil yang diperoleh bervariasi dan dapat dibandingkan.

\section{DAFTAR PUSTAKA}

Ahmad, A. B. (2016). The effects of $\mathrm{NaCl}$ priming on salt tolerance in sunflower germination and seedling grown under salinity conditions. African Journal of Biotechnology, 9(12), 1764-1770. https://doi.org/10.5897/ajb10.1019

Antika, L., Julianty, E., Miroah, Nurul, A., \& Hapsari, F. (2012). Pengukuran (Kalibrasi) Volume dan Massa Jenis Alumunium. Jurnal Fisika Dan Aplikasinya, 13(1), 22-28.

Genisa, J., Rahman, A. Nu., \& Tajuddin, K. (2019). Pemanfaatan Daun Paliasa (Kleinhovia hospita L) Sebagai bahan Alternatif dalam Mempertahankan Kesegaran Ikn kembung (Rastrellinger sp). Canrea Journal: Food Techology, Nutritons, and Culinary Journal, 2(1), $1-12$.

https://doi.org/10.20956/canrea.v2i1.1 89

Haryati, D., Nahdifa, L., Humairah, \& Abdullah, L. (2019). Ekstraksi dan Karakerisasi Gelatin Kulit Ikan Baronang (Siganus canaliculatus) dengan Metode Enzimatis Menggunakan Enzim Bromelin. Canrea Journal: Food Techology, Nutritons, and Culinary Journal, 2(1), 19-25.

https://doi.org/10.20956/canrea.v2i1.1 77

Kusnadi, D. C., Bintoro, V. P., \& Al-Baarrii, A. N. (2012). Daya Ikat Air, Tingkat Kekenyalan dan Kadar Protein Pada Bakso Kombinasi Daging Sapi dan Daging Kelinci. Jurnal Peternakan, 1(2), 28-31.

Laras, B., Arista Dwi, S. S., Suloi, A. N. F., \& Laga, A. (2019). Pengaruh Konsentrasi kentos kelapa Terhadap Degradasi Lemak Daging Ayam. Canrea Journal: Food Techology, Nutritons, and Culinary Journal, 2(1), 38-43. 
https://doi.org/10.20956/canrea.v2i1.1

76

Marnoto, T., Haryono, G., Gustinah, D., \&

Putra, F. A. (2016). Ekstraksi Tannin

Sebagai Bahan Pewarna Alami Dari

Tanaman Putrimalu (Mimosa Pudica)

Menggunakan Pelarut Organik.

Reaktor, 14(1), 39-45.

https://doi.org/10.14710/reaktor.14.1.3

9-45

Musta, R. (2018). Waktu Optimum

Hidrolisis Pati Limbah Hasil Olahan

Ubi Kayu (Manihot esculenta Crantz

var. Lahumbu) Menjadi Gula Cair

Menggunakan Enzim $\alpha$-Amilase Dan

Glukoamilase. Indonesian Journal of

Chemical Research, 5(2), 498-507.

Suarsana, I. N., Pontjo, B., Wresdiyati, T., \& Bintang, M. (2006). Sintesis

glikogen hati dan otot pada tikus diabetes yang diberi ekstrak tempe. Jurnal Veteriner, 11(3).

Sudjianto, A. T. (2007). Stabilisasi Tanah Lempung Ekspansif dengan Garam Dapur (NaCl). Jurnal Teknik Sipil, 8(1), 53-63.

Zulma, Z. (2018). Pengaruh Kesegaran Jasmani melalui Senam Sribu pada Siswa Kelas V SD N 21 Batang Anai Kabupaten Padang Pariaman. JPPI (Jurnal Penelitian Pendidikan Indonesia), 3(2), 67. https://doi.org/10.29210/02017118 